\title{
Two French Oil Terminals in the WWII
}

\author{
Giancarlo T. Tomezzoli \\ Etno-Archaeological Observatory, Munich, Germany \\ Email: gt21949@gmx.de
}

How to cite this paper: Tomezzoli, G. T. (2018). Two French Oil Terminals in the WWII. Archaeological Discovery, 6, 196-215. https://doi.org/10.4236/ad.2018.63011

Received: April 19, 2018

Accepted: June 5, 2018

Published: June 8, 2018

Copyright (C) 2018 by author and Scientific Research Publishing Inc. This work is licensed under the Creative Commons Attribution International License (CC BY 4.0).

http://creativecommons.org/licenses/by/4.0/

\begin{abstract}
Often, literature suggests that the Atlantic Wall was a set of support points (Stützpunkte) and fortresses (Festungen) extended from Norway up to Spain. This concept is not completely wrong but it masks the logistics involved in its defence activity. In this article the parallel destiny of the Talards and Bouchemaine oil terminals active in France during the German occupation and both having failed a complete destruction is considered. Original air recognition images, archive documents, information from experts and visits on the terrain helped a lot in clarifying their history, organization and preservation states. From previous publications and the present article, it appears now clear that the Atlantic Wall study must be addressed as an interdisciplinary matter with the contributions of experts in different fields.
\end{abstract}

\section{Keywords}

WWII, Atlantic Wall, Saint-Malo, Talards, Angers, Bouchemaine, Oil, Kerosene, Terminal, France

\section{Introduction}

Previous publications provided some hint about the Atlantic Wall logistics by presenting two structures involved in its construction (Tomezzoli, 2015; Tomezzoli \& Marzin, 2015) and a logistic base (Tomezzoli, 2016). Now sufficient material has accumulated concerning two other structures involved, this time, in its fuel supply. United by the common destiny to be active in France during the German occupation and both having failed a complete destruction, the Talards and the Bouchemaine oil terminals respectively in Saint-Malo and near Angers had parallel stories which are here considered.

\section{The Talards Oil Terminal (Saint-Malo)}

The Talards oil terminal was built on a side of an internal basin of the 
Saint-Malo harbour, named Mare aux Canards (Ducks Pond). It was skirted by a branch of the railway coming from the nearby Saint-Malo $S N C F$ station and by the metric railway line Rennes - La Mazière - Saint-Malo of the TIV (Tramways d'Ille et Villaine). From 1939 the oil terminal was operated by Les Pétrole de l'Ouest founded on $20^{\text {th }}$ January 1936, head office at 2 rue Joseph Sauveur, Rennes and the Societé Armoricaine des Carburants, head office at 8 quai de Richemond, Rennes. From 1940 the terminal was operated by Societédes Dépôts de Petrole de Cherbourg, head office at 42 rue de Washington, Paris 8 (Élysée District) together with Societé des Dépôts Côtiers, head office at the same address in Paris, which was also the head office address of the Societé Shell (Pottier, 2013) (Figure 1). The rapid German offensive in France on May-June 1940 caused the defeat of the French army and the retreat of the British Expeditionary Force toward the French ports for embarking toward Great Britain. A letter dated $27^{\text {th }}$ July 1989 of the Rear Admiral Howard-Johnson, let evocate those days in the following terms. On June 1940, tenth of thousands British soldiers were in Saint-Malo harbour, waiting for embarking. The Rear Admiral demolition group arrived in Saint-Malo on 17th June 1940 from Portsmouth on board of HMS Wild Swan, after a brief stop at Saint Helier (Jersey Island). During the stop, a meeting took place with the Commodore of the Saint Helier Yacht Club in which the Rear Admiral explained him that the Wild Swan has not to remain to Saint-Malo and, because of the orders, after the work, the group had to leave Saint-Malo on foot toward West. If the Yacht Club sent boats to Saint-Malo the departure of the group would have been simplified. After the embarking of most of the British soldiers, further disbanded soldiers arrived at the harbour often without weapons and sometime with cognac bottles generously offered by Frenchs. The group was formed by the Rear Admiral and 25 voluntaries and had eight tons of explosives for the demolition of the harbour facilities. They were all sailors with the exception of a military officer of the Royal Engineers; the only

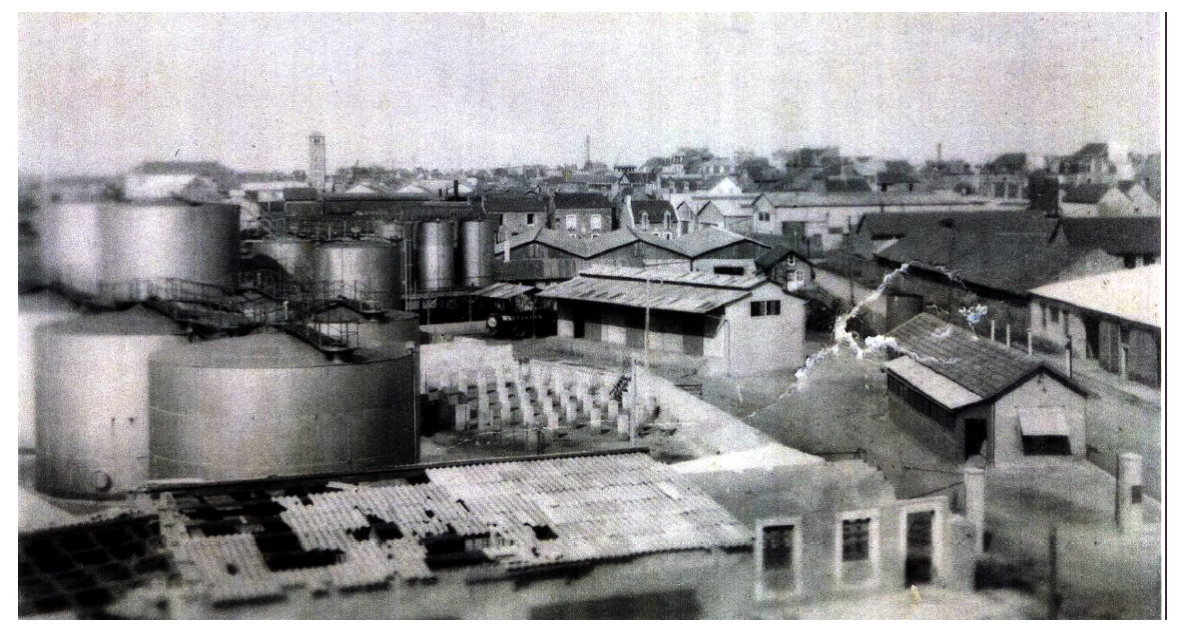

Figure 1. Talards oil terminal-pre-war image, on the left oil tanks, on the right entrance gate, on the foreground left the still existing square tower of the Civic Centre of the Louis Martin Avenue in front of the Commerce Chamber (Pottier, 2013; Archive Saint-Malo, 1940). 
expert in demolitions. The group had nothing to do with the soldiers' embarking, but in absence of gendarmes and French military units it taken all in the hands comprising the destruction of the cognac bottles. A group of disbanded soldiers arrived one day followed by a Belgian taxi with four British officers two of which injured. At the last moment Belgian nurses arrived on board of a magnificent ambulance. During the night they encountered German tanks on the road to Rennes. Up to that moment nobody knows that the Germans were so close. They told that the Germans were at Dôle. The only Dôle known by the Rear Admiral was on the way to Switzerland. Just at the moment of the Germans arrival, he realised that Dôle was actually Dol-de-Bretagne, $20 \mathrm{~km}$ from Saint-Malo.

Before to leave London the Rear Admiral received three hundred pounds in banknotes and the order to proceed to the demolitions under the orders of the French authorities. At the group arrival, the situation was chaotic, but the French Navy Commander in Saint-Malo was found. The Commander received no information from Paris or the Naval Prefecture in Normandy concerning the group mission. He beware the group and the explosives. He was Vessel Captain and the Rear Admiral a Frigate Captain at that time; therefore, the Commander was the French authority sought. After two days, the Commander authorised the Rear Admiral to put explosives at the basin sluices and at the oil tanks. Cars and trucks, often completely new British trucks, were parked in the city hippodrome. French guards all around the hippodrome prevented the group to bring these vehicles toward a beach and in the water. The group had no baggage and slept where it was possible, often on pavements. The group fed in a bistrot of a dock and this reduced the pounds received. The general De Gaulle appeal was diffused by the bistrot radio, but the Commander received no order Paris or elsewhere about how to react. At the end, the Commander convened the Rear Admiral urgently at the town hall together with other city authorities to receive the Germans. He ordered the Rear Admiral to do what he could. The group had no time for well demolish the harbour sluices, but just the time to burn the gasoline tanks. The German flag waved on the city hall when the group leaved the harbour thanks to the boats and the courage of the of Saint Helier Yacht Club members (Pottier, 2013). A further letter of the Rear Admiral of $28^{\text {th }}$ July 1989 let still to evocate those days in the following terms. Lines of railway wagons with military supplies and clothing were on the harbour docks. The HMS Wild Swan crew provided the Rear Admiral with eight smoke floats which he lit in the narrow streets of Saint-Malo. A westerly breeze propagates a dense smoke screen which he hoped would have delayed the German entrance. He wondered if it did that. When Saint-Malo crowds were plundering all the stores, he remarked a chap who said in French "we will only be left with our eyes to cry". Without the Saint Helier Yacht Club he supposed not to be alive today (Pottier, 2013). The Wild Swan was lost on $17^{\text {th }}$ June 1942 because of an air bomb in the Gascoigne Gulf. 
A thick column of smoke from the burning terminal tanks remained visible for days. Avro Ansons of 48th RAF Squadron patrolling off the French coast documented columns of smoke and flames from the Talards oil tanks (Figure 2, Figure 3) set on fire by the Howard-Johnson's demolition group. However, the terminal was not completely destroyed and it was rapidly put back in operation (Brichet \& Peyle, 2005) for the supply of kerosene to the Luftwaffe fighters and bombers stationed at the nearby airfield of Dinard-Pleutuit (Lippmann, 2012; Tomezzoli et al., 2013; Tomezzoli, 2014; Dahiot et al., 2009), participating to the battle of Britain (10 $0^{\text {th }}$ July - $31^{\text {st }}$ October 1940). A daily supply of kerosene to the airfield was possible by road, crossing the Saint-Hubertus bridge $15 \mathrm{~km}$ south of Saint-Malo or by using the ferry Saint-Malo-Dinard. In both the cases this would have caused unacceptable delivery delays. To overcome this problem, the German Luftwaffe decided the requisition of the self-propelled barges in the harbour. Each barge filled its bunkers at the Talards terminal, leaved Saint-Malo harbour, reached the mouth of the Rance river and docked at a mooring peer near La Richardais. There a pumping station extracted the kerosene from the barges and sent it to the airfield by means of a pipeline. The barges were a dozen comprising Esso, Naphta I, Naphta II, Marie-Therese, Chantilly, Galem and Molan (Brichet \& Peyle, 2005).

The oil terminal $\left(48^{\circ} 38^{\prime} 38.34^{\prime \prime} \mathrm{N}, 2^{\circ} 00^{\prime} 41.61^{\prime \prime} \mathrm{W}\right.$ ) (Figure 4) was definitively dismantled at the beginning of the years two thousands. Several visits in the harbour in looking for possible terminal surviving components provided no result.

\section{The Bouchemaine Oil Terminal (Angers)}

The Bouchemaine oil terminal construction began on 1939, following a French law which obliged the edification of oil terminals outside sea harbours. The platforms construction and the tanks mounting were completed at the beginning

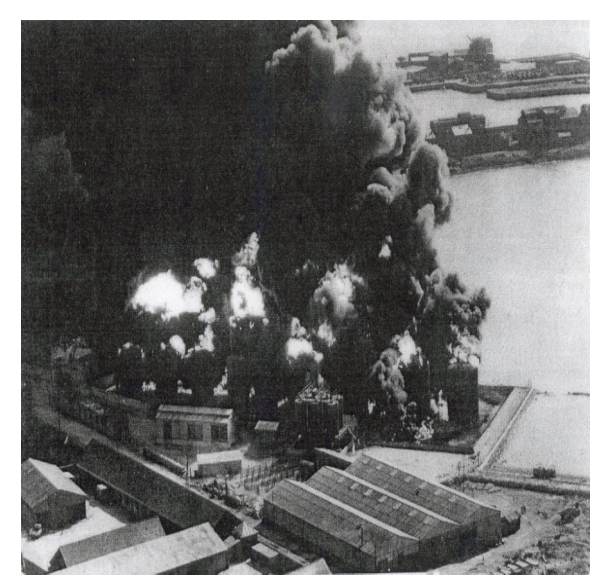

(a)

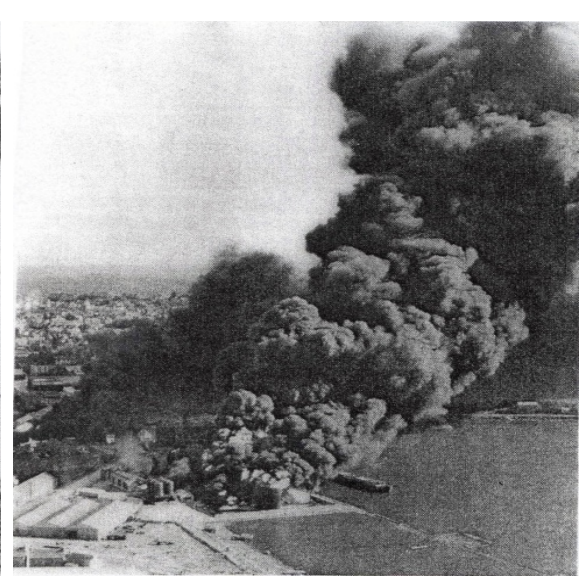

(b)

Figure 2. Talards oil terminal-(a) tanks on fire (Imperial War Museum, RAF Coastal Command); (b) smoke column above the tanks (Imperial War Museum, RAF Coastal Command) on the right a tanker at the mooring peer. 


\section{E}

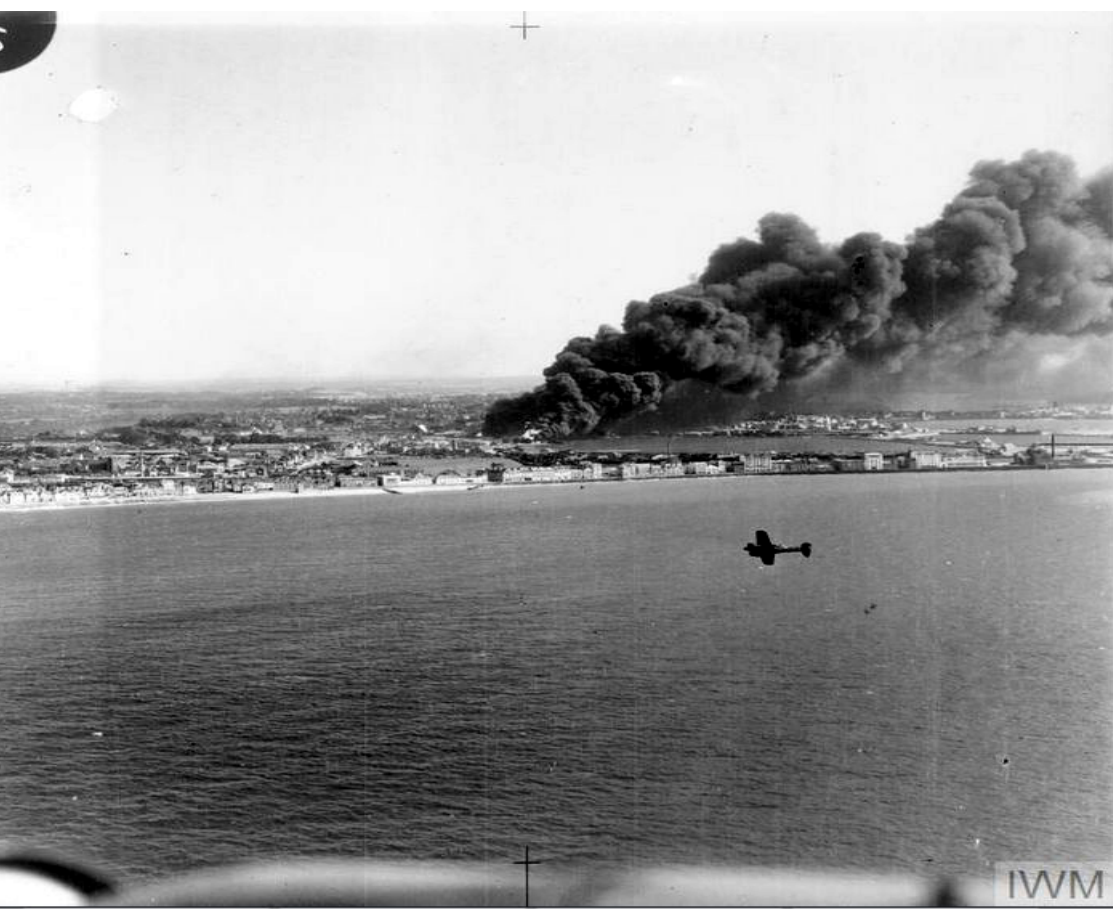

Figure 3. Talards oil terminal on fire (Imperial War Museum, RAF Coastal Command, Cat.: C 1802).

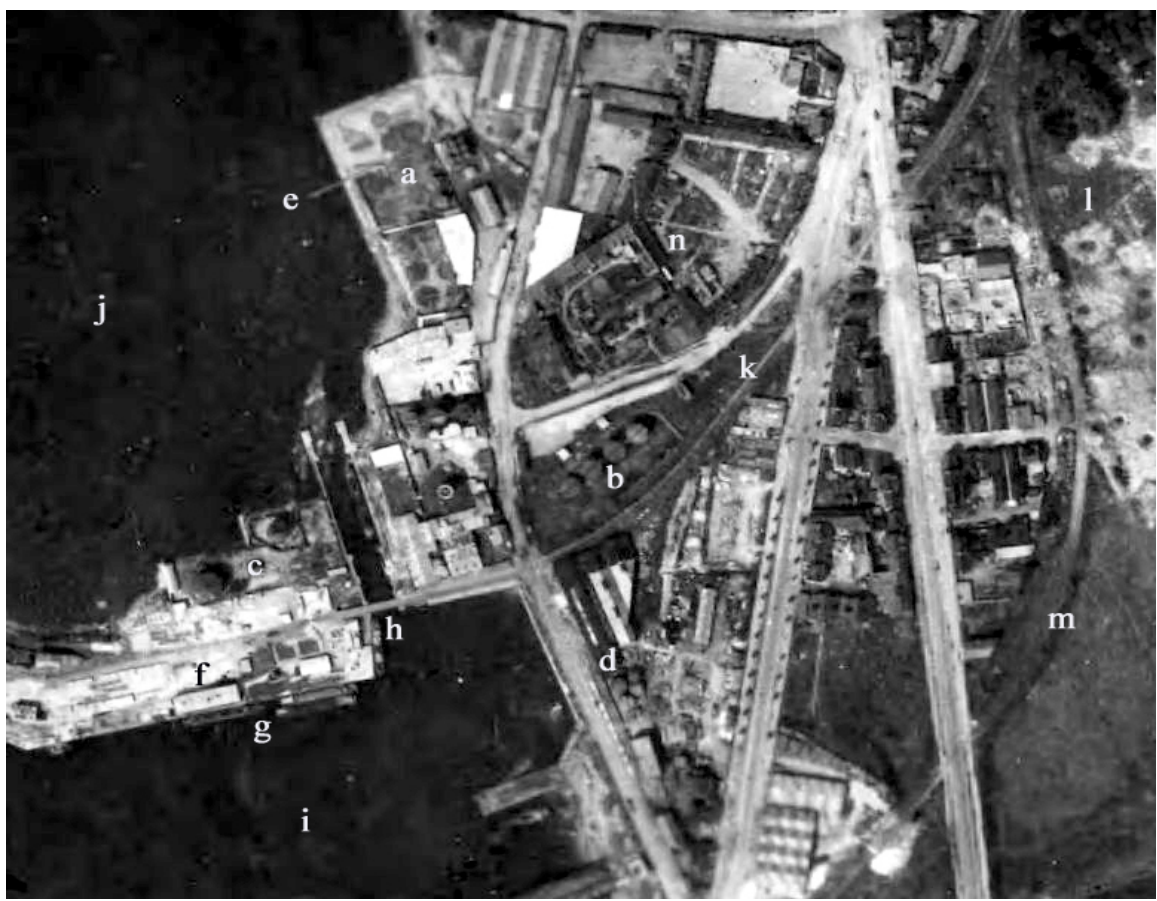

Figure 4. Talards oil terminal organization-a: 1st area-main tanks burned by the Howard-Johnson's demolition group; b: 2nd area; c: 3rd area; d: 4th area, e: mooring peer; f: degaussing station (Tomezzoli \& Pottier, 2016); g: moored barges; h: movable bridge; i: Bouvet basin; j: Jacques Cartier basin - Mare aux Canards; k: railway; 1: bombarded zone; m: railway; n: Talards casern. (Mission identification: C1115-0331_ 1944_106G1614_4005, cliché n 4005, scale: 1/10313, cliché type: Argentique, Date de prise de vue: $24 / 07 / 1944)$. 
of 1940. The oil terminal comprised four tanks coded A, B, D and E, each $16.1 \mathrm{~m}$ in diam., $10.5 \mathrm{~m}$ height, $2140 \mathrm{~m}^{3}$ in capacity, ten tanks coded 1 to 10 each of 50 $\mathrm{m}^{3}$ in capacity, a dock with a pumping station on the board of the Maine river, a pipeline, a pipeline metal bridge on the $S N C F$ railway, a rail depot for receiving tank trains, a charging station for tank trucks, a site canalization net and an anti-fire station (Figure 5). The refuelling of the oil terminal was assured by self-propelled barges and tankers coming from the refinery of Donge at the mouth of the Loire river and by tank trains. The pumping station extracted the

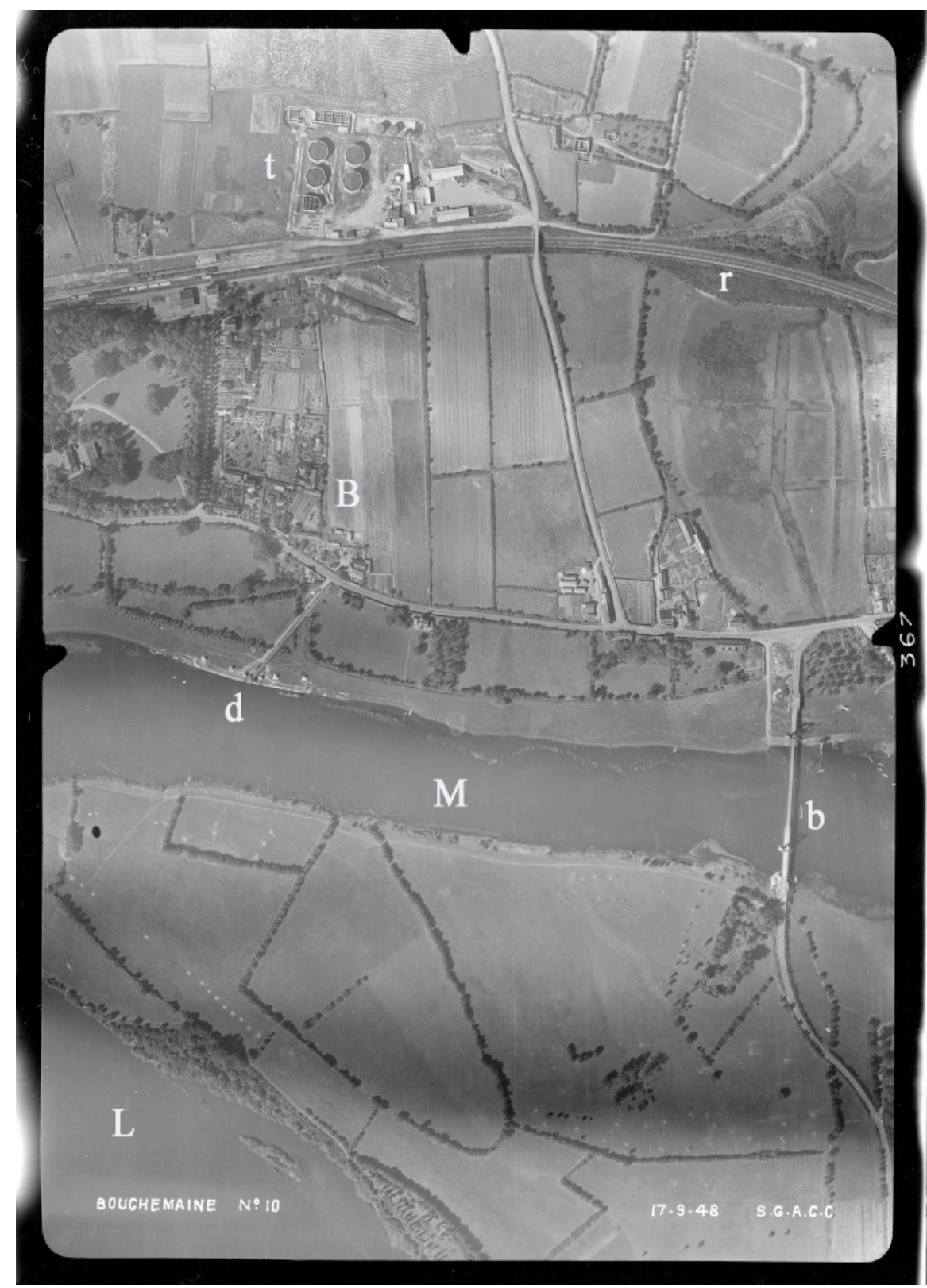

Figure 5: Bouchemaine-b: damaged suspended bridge; d: oil dock; r: railway; t: oil terminal; B:Bouchemaine; L: Loire river; M: Maine river.(Mission identification: C93PHQ8041_1948_CDP3032_0010, cliché n 10, scale: 1/5034, cliché type: Argentique, Date de prise de vue: 17/09/1948). 
fuel from the tankers and pumped it in the pipeline. Responsible of the oil terminal was Mr J-E. Chaffot president and director general ( $P D G)$ of Les Pétroles de l'Ouest (the same company operating the Talards oil terminal), $P D G$ of Béton Cellulaire and manager of Les Sablières de Bretagne. Administrators were Mr M. Laussel, war prisoner on 1941, and Mr Denoual. The tanks A-B were managed by Les Pétroles de l'Ouest, the tanks D-E were sold on $31^{\text {st }}$ July 1942 to Pétrole Jupiter (Shell). The personnel comprised 18 workers and employees. In period of the terminal reconstruction (March 1945 - November 1946) their salaries varied between 10.5 and 30 Frs per hour with a taxation up to $67 \%$.

An assurance policy was negotiated on $29^{\text {th }}$ Mai 1940 for the risk of burning. The administration council of $6^{\text {th }}$ September 1940 confirmed the normal functioning of the oil terminal notwithstanding the war. From $12^{\text {th }}$ June 1941 to 8 th August 1944 the oil terminal was under requisition of the German Kriegsmarine.

A 1943 administrative report made apparent that the incomes from the fuel sale was practically nothing and that the only benefits came from the rent of the fuel tanks, the fees payed by the Kriegsmarine for the terminal requisition and from other minor activities. On 1944 a sum of 49,726 Frs was affected to a provision chapter for the war risks (Oil Terminal Archive, 2018).

During the requisition were built: an octagonal concrete wall $10.5 \mathrm{~m}$ height with a variable thick of $1 \mathrm{~m}$ at the base to $0.80 \mathrm{~m}$ at the top around each tank A-E, a six side wall around the tanks 1 to 10 , a bunker at the terminal entrance, a further bunker and a building. The Kriegsmarine proceeded to new installations comprising some groups of motor-cycle pumps Renault-Guinard of $180 \mathrm{~m}^{3}$ and tubes larger in diameter ( 8 ", 10 ").

The damages to the oil terminal came from the Kriegsmarine requisition and from allied bombardments on July 1944 in which about 24 - 29 bombs hit the terminal site. Three damages reports of $7^{\text {th }}$ November 1944, $2^{\text {nd }}$ April 1945 and $12^{\text {th }}$ March 1946 estimated the damages as follows: tank A damaged at $60 \%$, tank B at $30 \%$, footbridge between the two tanks and accessing stair completely destroyed, tank $\mathrm{E}$ about 40 holes on the cap, tank D about 20 holes on the cap, footbridge between the two tanks and accessing stairs slightly distorted by projectile impacts, 1 to 10 tanks 66 perforations on nine tanks, three houses (offices, concierge, WC) damaged, the pipeline metal bridge partially destroyed, $209 \mathrm{~m}$ of pipes on the site partially destroyed, 1 hangar damaged at $80 \%$, entrance portal and barriers destroyed at $100 \%$.

At its retreat the Kriegsmarine brought away a charging post for trucks, three electro-pumps Mouvex of $28 \mathrm{~m}^{3}$, two of the three counters Thémis of 2500 litres of capacity, pipes either in place or in stock for a length of $1221 \mathrm{~m}$, a basin of $5 \times$ $3 \mathrm{~m}$, an oil remover, bronze valves, soldering material and other materials.

On $24^{\text {th }}$ November 1944 a sum of $3,540,000$ Frs was authorized for the terminal reconstruction, which started on March 1945 and terminated on November 1946 (Oil Terminal Archive, 2018). Les Petrole de l'Ouest was definitively acquired by the group Elf on 1989 . 


\subsection{The Oil Dock}

The oil dock visit took place on 4th January 2018. The identified components were the following.

The dock platform (Figure 6), about $126 \times 27 \mathrm{~m}$, completely covered by grass, about $450 \mathrm{~m}$ far from the oil terminal. Nine well preserved minor columnar bollards, each formed by a concrete prismatic column about $0.5 \mathrm{~m}$ large and $1.5 \mathrm{~m}$ height with a small metallic bollard at the top, were aligned on its river side. Five main columnar bollards a, b, d, e, f, each having a concrete square base about 5 $\mathrm{m}$ large with a superimposed concrete octagonal column of about $3 \mathrm{~m}$ in long diagonal and $3 \mathrm{~m}$ height with a metallic railing and a metallic bollard at the top, were aligned in its middle. Some well preserved concrete supports of an original metallic barrier and two prismatic, concrete, white columns marking a dock entrance were aligned in its land side (Figure 7(b), Figure 7(c), Figure 7(e)).

Bollard a $\left(47^{\circ} 25^{\prime} 0.72 \mathrm{~N}, 0^{\circ} 36^{\prime} 44.98^{\prime \prime} \mathrm{W}, 16.53 \mathrm{~m}\right.$ ) (Figure $7(\mathrm{~b})$ ) was in good preservation state with possible traces of white painting. Its square base was covered by grass. It presented two steps on four opposed column sides, a metallic stair on two opposed column sides, a railing and a blue painted bollard on its top. Two tubes of a possible ground system were fixed on two column sides.

Bollard b $\left(47^{\circ} 24^{\prime} 59.91^{\prime} \mathrm{N}, 0^{\circ} 36^{\prime} 45.57^{\prime \prime} \mathrm{W}, 16.45 \mathrm{~m}\right)$ (Figure 7(c), Figure 7(d)) was in good preservation state with possible traces of white painting. Its square base was covered by grass. It presented two steps on four opposed column sides, a metallic stair on four opposed column sides, a railing and a grey painted bollard on its top. One mooring ring, about $30 \mathrm{~cm}$ in diameter was attached on four opposed column sides.

Bollard $\mathrm{c}$ and the superimposed pumping station have disappeared (Figure $7(\mathrm{e})$ ).

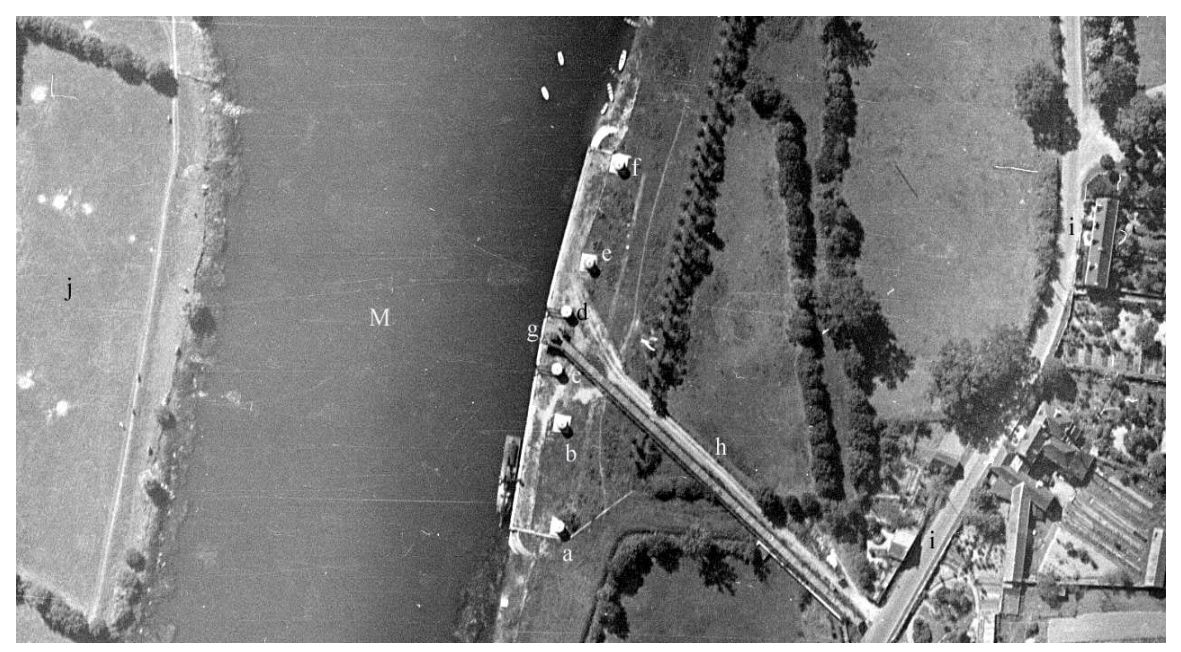

Figure 6. Bouchemaine oil dock—a, b: main columnar bollards; c: disappeared main columnar bollard; d, e, f: main columnar bollards; g: pumping station; h: dock's access road-pipeline road; i: actual rue Chevrière; j: possible bomb impact craters, M: Maine river. (Mission identification: C93PHQ8041_1948_CDP3032_0010, cliché n ${ }^{\circ} 10$, scale: 1/5034,cliché type: Argentique, Date de prise de vue: 17/09/1948). 


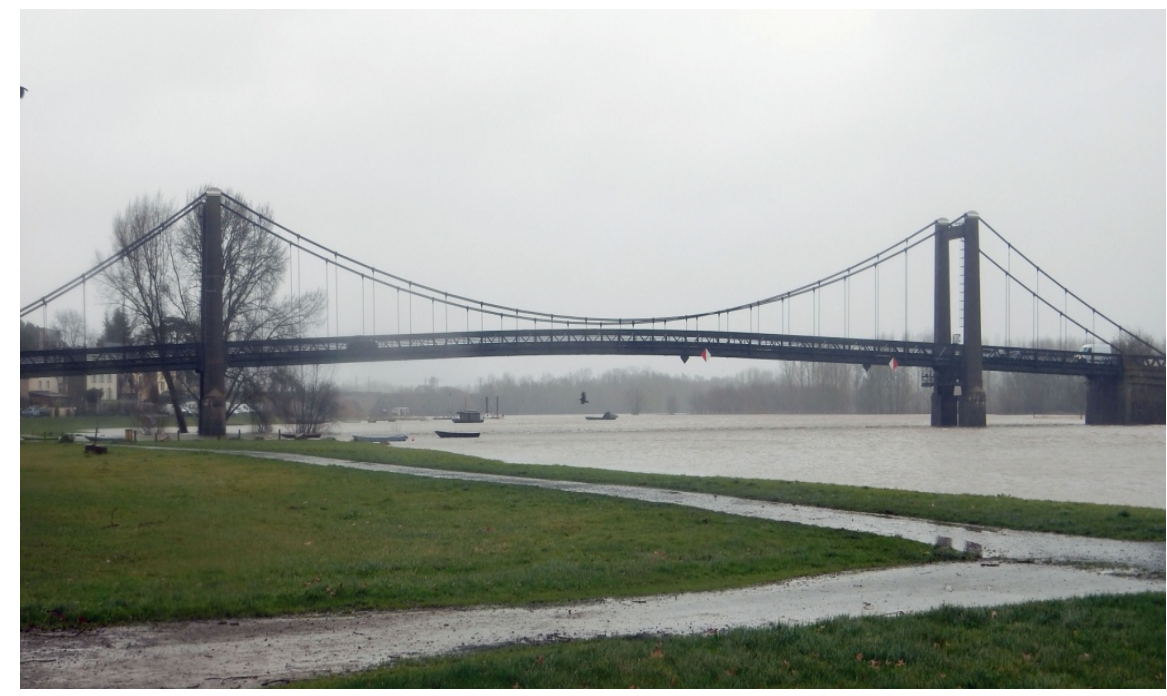

(a)

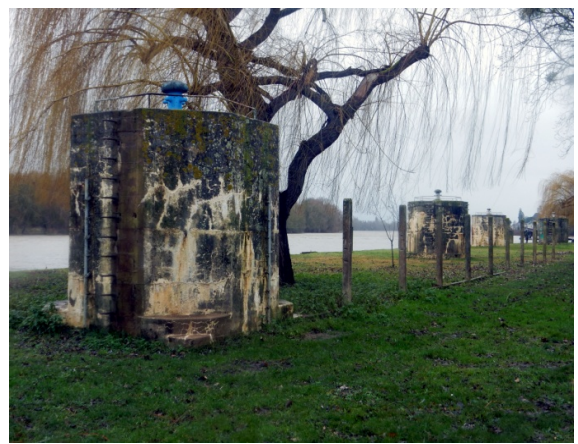

(b)

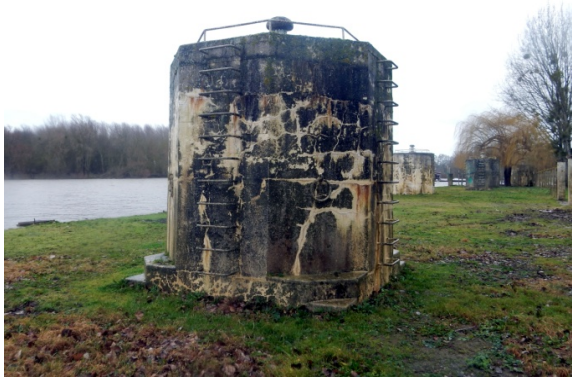

(d)

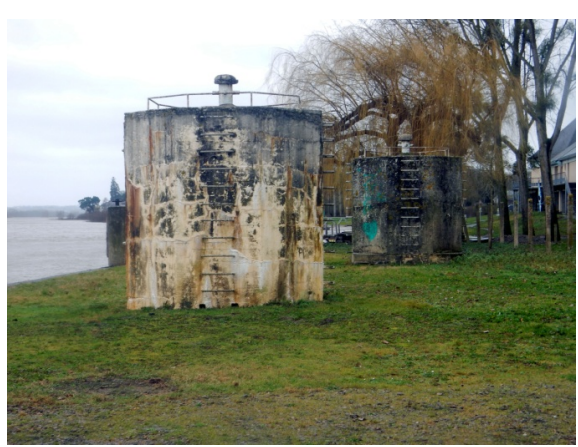

(f)

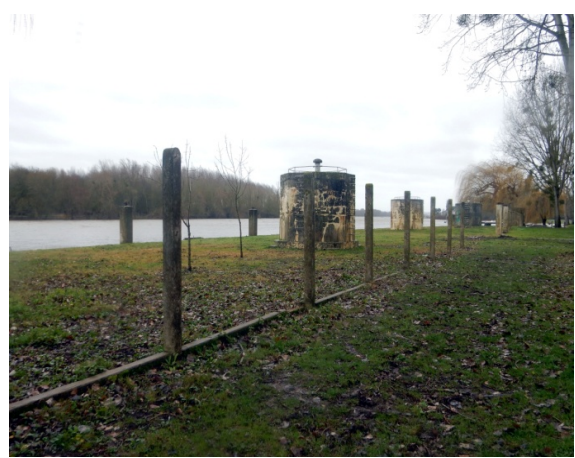

(c)

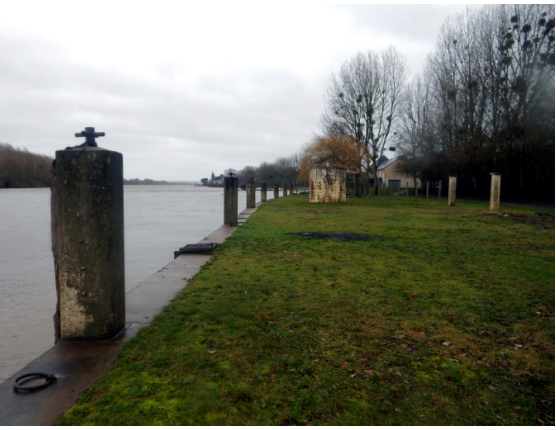

(e)

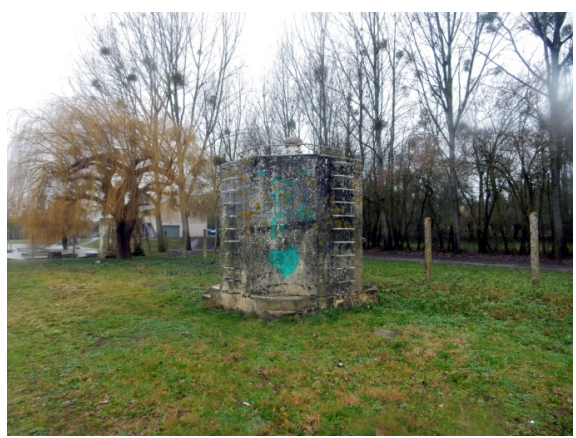

(g) 


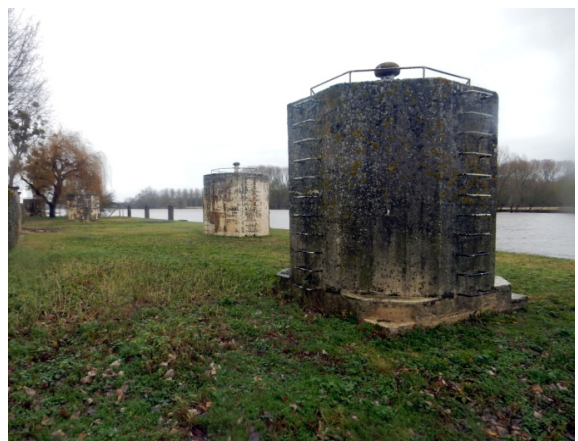

(h)

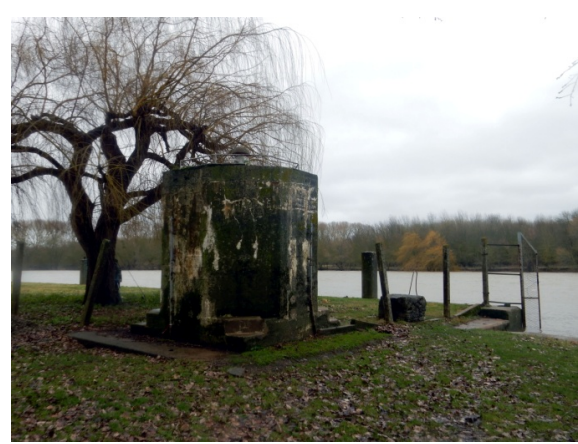

(i)

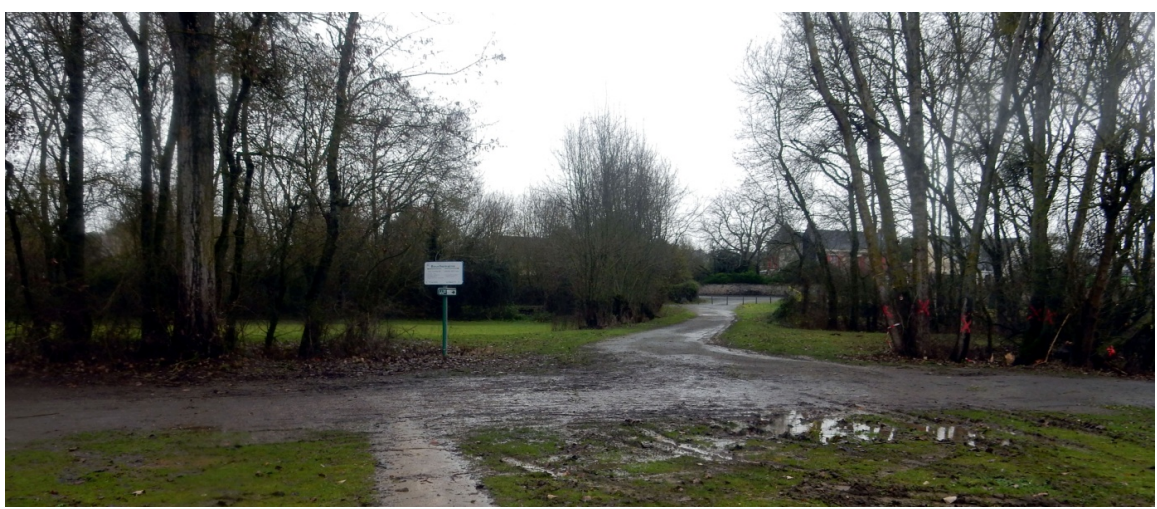

(j)

Figure 7. Bouchemaine oil dock-(a) suspended bridge; (b) platform and columnar bollard a, on the foreground the columnar bollard (b), (d), (e) and the supports of an original metallic barrier; (c) platform and columnar bollard b on the foreground the columnar bollard (d), (e) and supports of the barrier; (d) columnar bollard (b), details; (e) platform, location of the disappeared columnar bollard (c) with superimposed pumping station, on the left and on the foreground left the minor columnar bollards, on the foreground right entrance, concrete white columns and columnar bollard (d); (f) columnar bollard d with two small square holes at a stair lower side; (g) columnar bollard (e); (h) columnar bollard (e), on the fore-ground the columnar bollard (d); (i) columnar bollard (f); (j) unpaved pipeline road.

Bollard d ( $47^{\circ} 24^{\prime} 59.03^{\prime \prime} \mathrm{N}, 0^{\circ} 36^{\prime} 46.24^{\prime \prime} \mathrm{W}, 16.49 \mathrm{~m}$ ) (Figure 7(e), Figure 7(f)) was in good preservation state with possible traces of a white painting. Probably deprived of a square base (Figure $7(f)$ ), it presented a metallic stair on four opposed column sides, a railing and a grey bollard on its top. Minor mooring rings were present on the column sides and two small square holes at a stair lower side let suspect that its interior was empty.

Bollard e $\left(47^{\circ} 24^{\prime} 58.75^{\prime \prime} \mathrm{N}, 0^{\circ} 36^{\prime} 46.81^{\prime \prime} \mathrm{W}, 16.44 \mathrm{~m}\right.$ ) (Figure 7(g), Figure 7(h)) was in good preservation state without traces of painting. Its square base was covered by grass. It presented two steps on four opposed column sides, a metallic stair on four opposed column sides, a railing and a white painted bollard on its top. One small mooring ring, about $5 \mathrm{~cm}$ in diameter was present on four opposed column sides.

Bollard f $\left(47^{\circ} 24^{\prime} 58.08^{\prime \prime} \mathrm{N}, 0^{\circ} 36^{\prime} 47.71^{\prime \prime} \mathrm{W}, 16.40 \mathrm{~m}\right.$ ) (Figure $7(\mathrm{i})$ ) was in good preservation state, with possible traces of white painting. Its square base 
emerged from the grass. It presented two steps on four opposed column sides, no metallic stair on the column sides, a railing and a white painted bollard on its top. Two tubes of a possible ground system were fixed on two column sides.

\subsection{The Oil Pipeline}

The oil pipeline connected the oil dock $d$ to the oil terminal $t$ (Figure 8). The pipeline began at the pumping station initially located between the bollards $\mathrm{c}, \mathrm{d}$. Subsequently, the pumping station was elevated on the top surface of bollard $c$ and, in recent years a metallic platform was added for facilitating oil barges and tankers discharging (Figures 9(a), Figures 9(b)). From the pumping station, the pipeline, partly buried, continued on one side of an unpaved road and then it turned west along the actual rue Chevrière, before to bend at a right angle to cross cultivated fields up to a metal bridge on the $S N C F$ railway and enter the oil terminal. The bollard $c$, the pumping station and the metallic platform were demolished in 2012 (Figures 9(a)-(d)). The pipeline was probably dismantled or remains buried in the terrain and no longer visible.

\subsection{The Oil Terminal}

Figure 10 shows the oil terminal organization and is particularly touching because its high quality permits, by enlargement, to distinguish a train formed by a puffing steam locomotive towing 35 wagons crossing the Bouchemaine stations and transiting under the pipeline metal bridge on the faraway day of $17^{\text {th }}$ September 1948

The oil terminal visit took place on $4^{\text {th }}$ January 2018. The terminal identified components were the following.

The main terminal entrance g, comprising a well preserved white painted German small rectangular bunker $\left(47^{\circ} 25^{\prime} 9.32^{\prime \prime} \mathrm{N}, 0^{\circ} 37^{\prime} 1.24^{\prime \prime} \mathrm{W}\right)$ (Figure $11(\mathrm{a})$ )

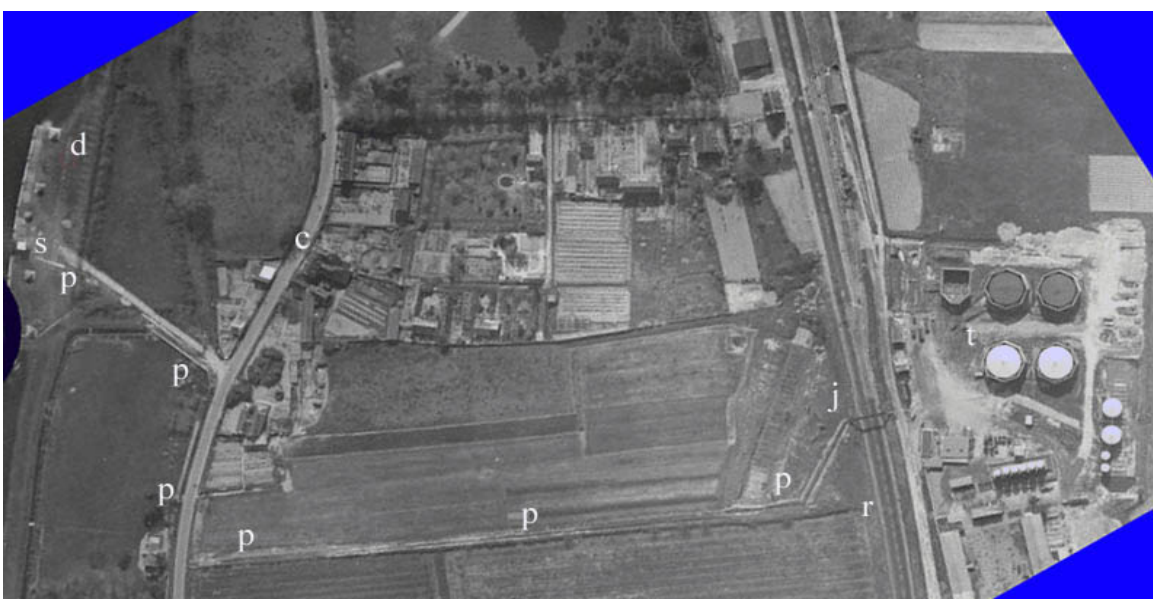

Figure 8. oil pipeline-c: rue Chevrière; $d$ : oil dock; s: pumping station on bollard $\mathrm{c}$; $\mathrm{p}$ : pipeline; j: pipeline metal bridge on the $S N C F$ railway; r: $S N C F$ railway; t: oil terminal. (Mission identification: C1522_0281_1954_CDP860_0358, cliché n³58, scale: 1/4090, cliché type: Argentique, Date de prise de vue: 12/04/1954). 


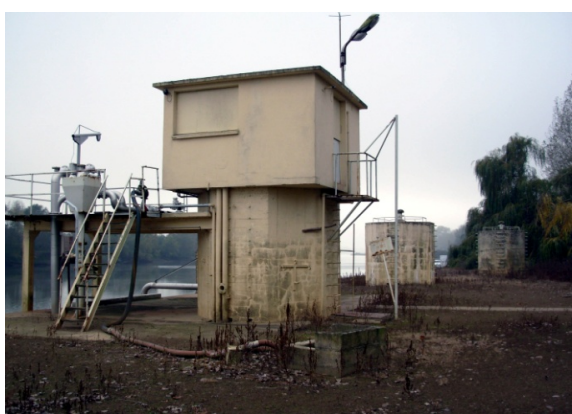

(a)

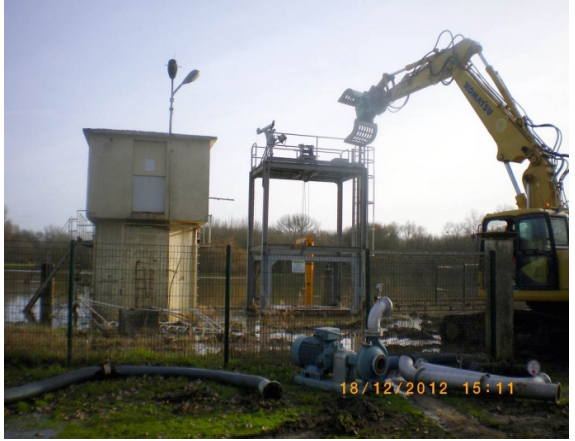

(c)

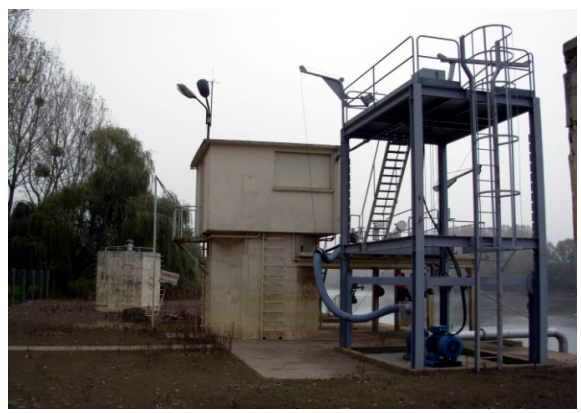

(b)

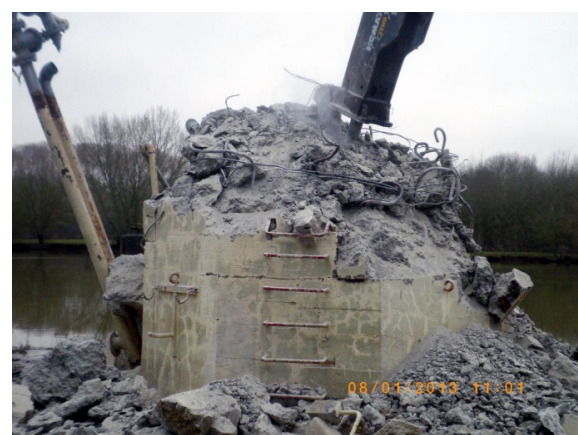

(d)

Figure 9. Pumping station and bollard c demolition-(a) side view, on the left the added metallic platform with oil discharging tubes, on the foreground right the columnar bollards d, e (courtesy Mr F. Guillaume, $07^{\text {th }}$ November 2006); (b) side view, on the foreground left the columnar bollard $b$, on the right the metallic platform with oil discharging tubes (courtesy Mr F. Guillaume, $07^{\text {th }}$ November 2006); (c) platform and pumping station demolition (courtesy Mr F. Guillaume); (d) bollard c demolition (courtesy Mr F. Guillaume).

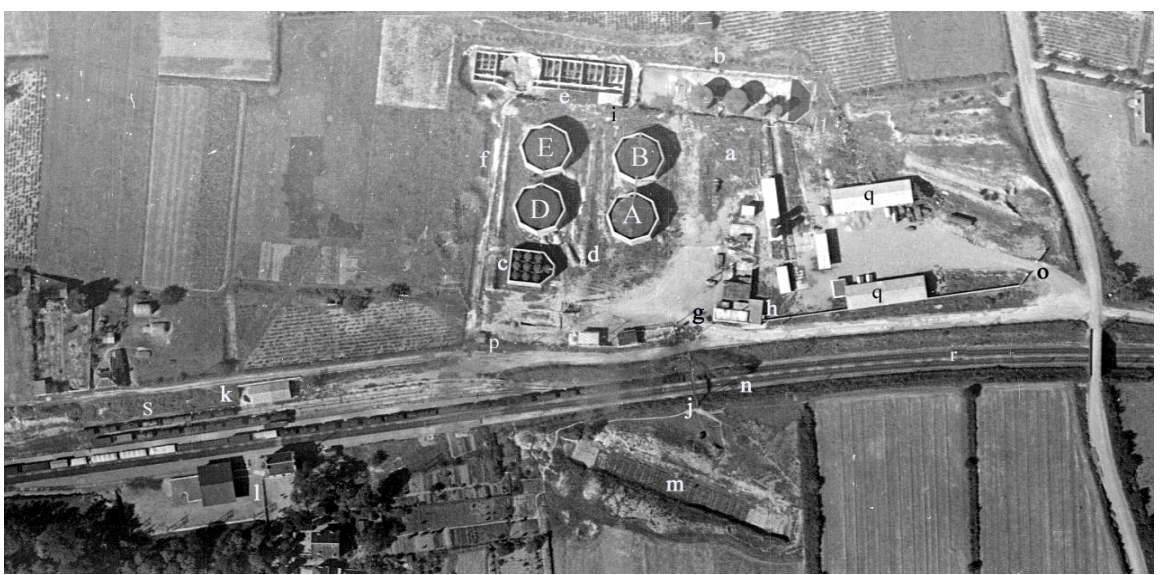

Figure 10. Bouchemaine oil terminal—a: 1st area; b: 2nd area; c: six side wall with tanks 1 to $10 ; \mathrm{A}, \mathrm{B}, \mathrm{D}, \mathrm{E}$ labelled octagonal walls and corresponding oil tanks; d: possible disappeared structure; e: damaged building; f: protected passage to the building e or anti-tank trench; g: terminal main entrance/exit; h: bunker; i: bunker; j: pipeline metal bridge; $\mathrm{k}$ : Bouchemaine freight station; 1 : Bouchemaine passenger station; m: excavation; n: train; o: entrance/exit p: minor construction; q: hangar; r: $S N C F$ railway line, s: railway depot. (Mission identification: C93PHQ8041_1948_CDP3032_0010, cliché n ${ }^{\circ} 10$, scale: 1/5034, cliché type: Argentique, Date de prise de vue: 17/09/1948). 


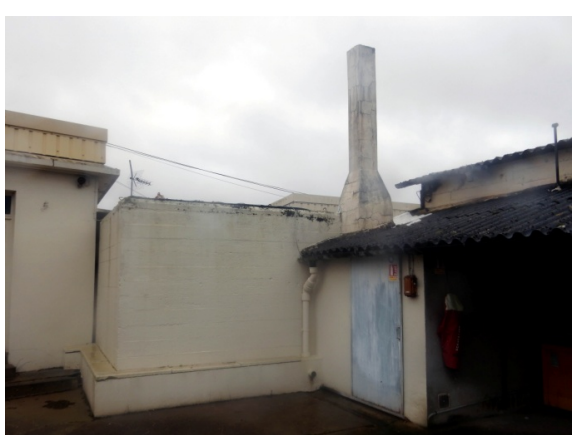

(a)

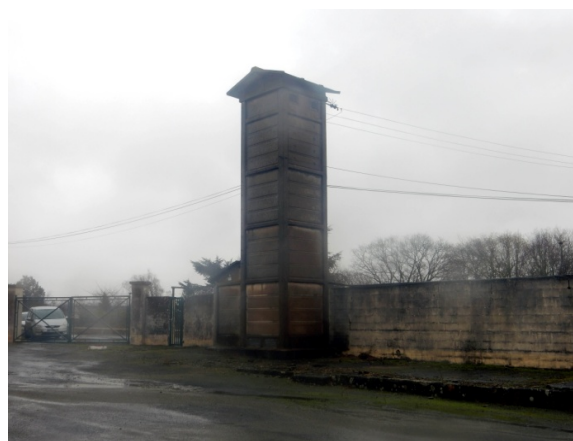

(b)

Figure 11. Bouchemaine oil terminal-(a) small German bunker $h$ at the entrance; (b) after war electrical distribution cabin.

about $9 \times 4 \mathrm{~m}$. The nearby electrical distribution cabin, not present in Figure 10, was built well after the war.

A well preserved oval concrete platform $\left(47^{\circ} 25^{\prime} 9.44^{\prime \prime} \mathrm{N}, 0^{\circ} 37^{\prime} 3.63^{\prime \prime} \mathrm{W}\right)$ (Figure 12) about $7 \times 3 \mathrm{~m}, 30 \mathrm{~cm}$ high with two bases for vertical structures on its surface.

Octagonal wall A $\left(47^{\circ} 25^{\prime} 8.45^{\prime \prime} \mathrm{N}, 0^{\circ} 37^{\prime} 3.82^{\prime \prime} \mathrm{W}\right)$ (Figure 13) about $20 \mathrm{~m}$ in long diagonal, still protecting the original tank refurbished several times after the war. It presented a three steps external structure with some large concrete superficial failures that left uncovered rods of the internal armour. On one side was a slightly eroded white board with the label A G8 $1897 \mathrm{M}^{3}$ indicating a tank capacity inferior to the above mentioned capacity of $2140 \mathrm{~m}^{3}$. On another side a circular, yellow metallic cover marked with a black label A closed the access to the tank protected by the wall.

Octagonal wall B $\left(47^{\circ} 25^{\prime} 8.84^{\prime \prime} \mathrm{N}, 0^{\circ} 37^{\prime} 4.81^{\prime \prime} \mathrm{W}\right)$ (Figure 12) about $20 \mathrm{~m}$ in long diagonal, still protecting the original tank refurbished several times after the war. It presented a three steps external structure with some local concrete superficial failures leaving uncovered rods of the internal armour. On one side was an eroded white board with the label B G8 $1897 \mathrm{M}^{3}$. On another side a circular, yellow metallic cover marked with a black label B closed the access to the tank protected by the wall.

Octagonal wall D $\left(47^{\circ} 25^{\prime} 7.44^{\prime \prime} \mathrm{N}, 0^{\circ} 37^{\prime} 4.71^{\prime \prime} \mathrm{W}\right)$ (Figure 14) about $20 \mathrm{~m}$ in long diagonal, still protecting the original tank refurbished several times after the war. It presented a three steps external structure with some local concrete superficial failures, leaving uncovered rods of the internal armour, and projectile impact cavities due to air attack. On one side was a white board whose label B G8 1897 $\mathrm{M}^{3}$ was abraded and covered by a blue, square board with a white label Er. On another side a circular, yellow metallic cover marked with a black label D closed the access to the tank protected by the wall.

Octagonal wall E $\left(47^{\circ} 25^{\prime} 7.85^{\prime \prime} \mathrm{N}, 0^{\circ} 37^{\prime} 5.7^{\prime \prime} \mathrm{W}\right)$ (Figure 15) about $20 \mathrm{~m}$ in long diagonal, still protecting the original tank refurbished several times after the war. It presented a three steps external structure with some local concrete superficial 


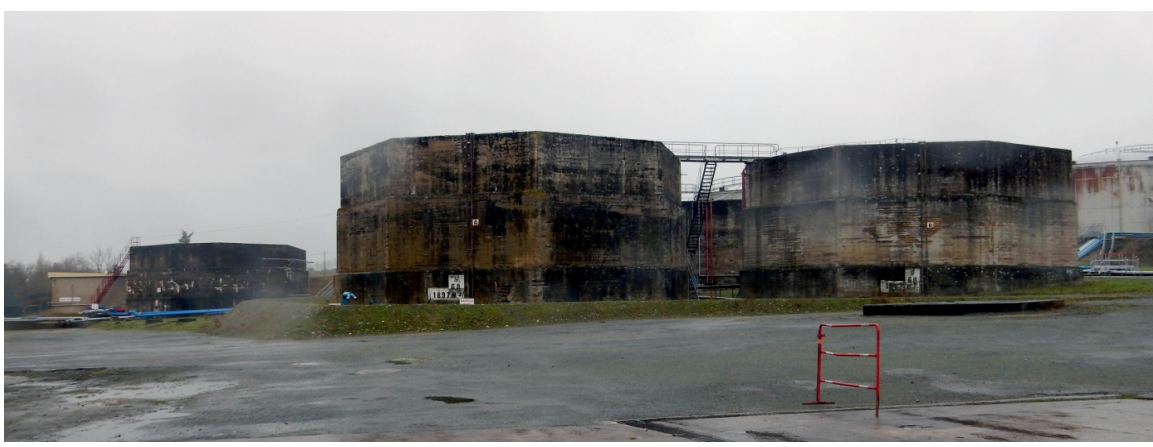

Figure 12. Bouchemaine oil terminal $1^{\text {st }}$ area-on the left the six sides wall, in the middle octagonal wall $\mathrm{A}$, on the right octagonal wall $\mathrm{B}$, near the octagonal wall $\mathrm{B}$, on the ground, the oval platform.

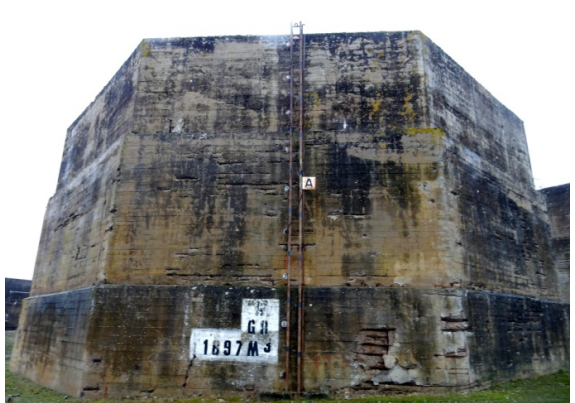

(a)

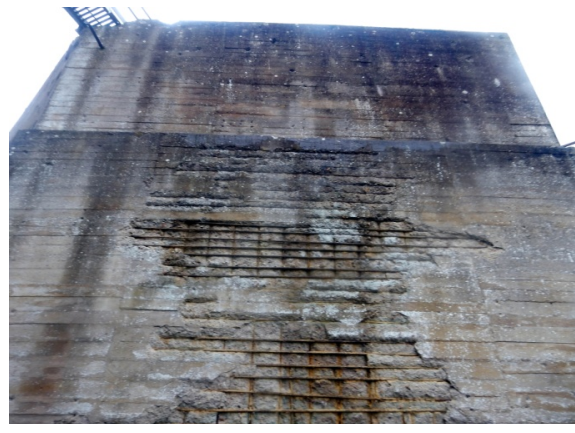

(b)

Figure 13. Octagonal wall A-(a) three steps external structure with white board; (b) local concrete superficial failures.

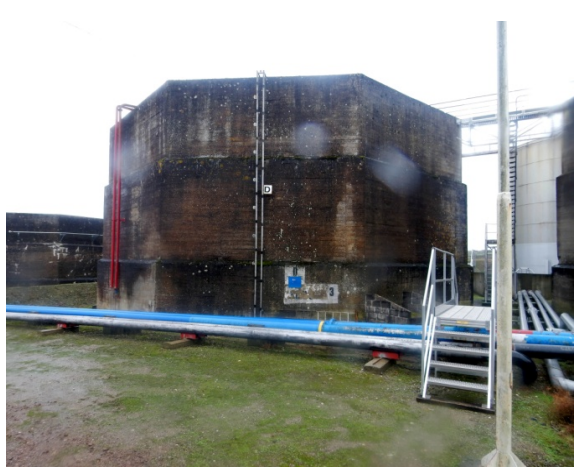

(a)

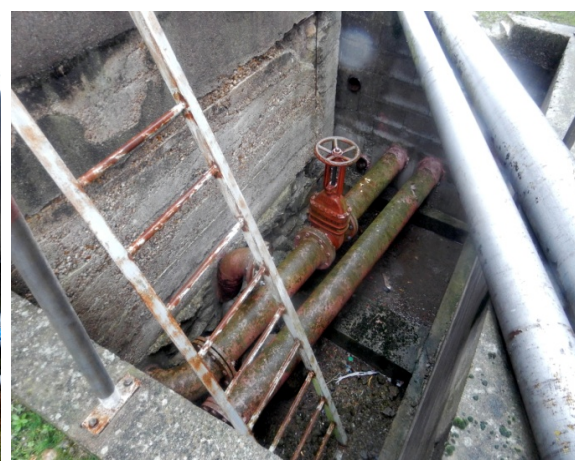

(b)

Figure 14. octagonal wall D-(a) external structure with white board covered by a square, blue board; (b) concrete pit with connection pipes.

failures leaving uncovered rods of the internal armour and projectile impact cavities due to air attack. On one side was a white board whose label B G8 1897 M3 was abraded and covered by a blue, square board with a square, white label. On another side was a circular, yellow metallic cover marked with a black label E closed the access to the tank protected by the wall. The access was a circular, metallic passage in the wall, about $1 \mathrm{~m}$ in diameter. The wall internal structure was vertical with no steps and in perfect preservation stage showing the traces of 


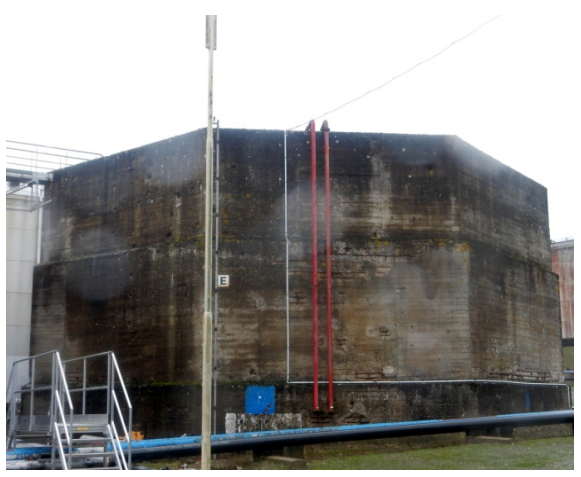

(a)

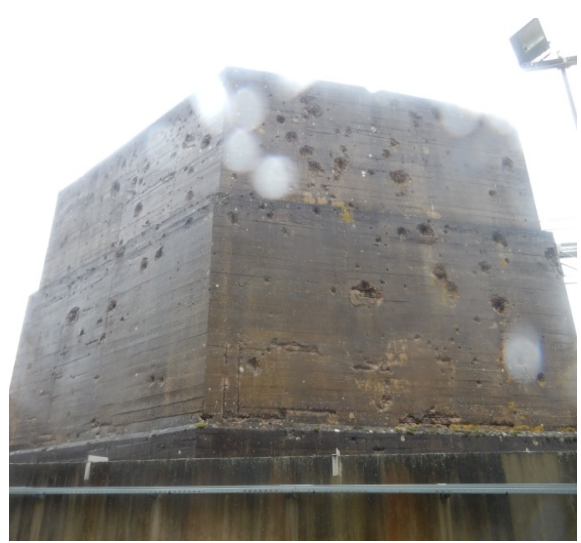

(c)

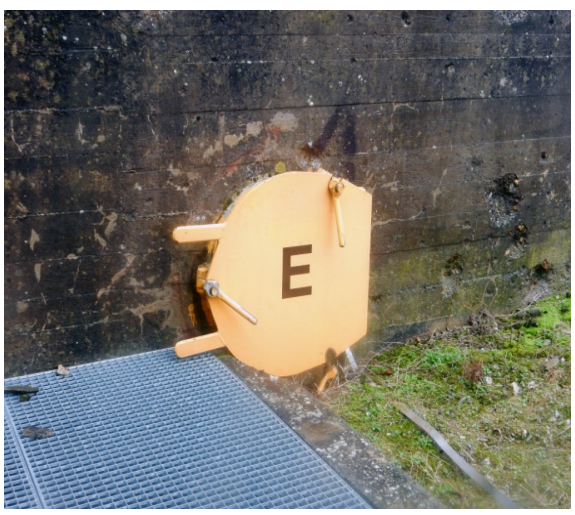

(e)

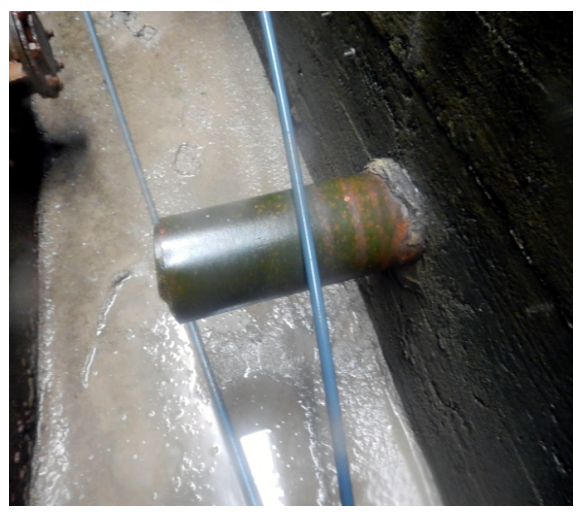

(g)

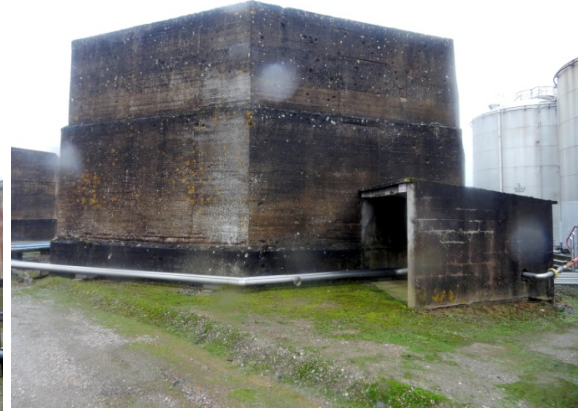

(b)

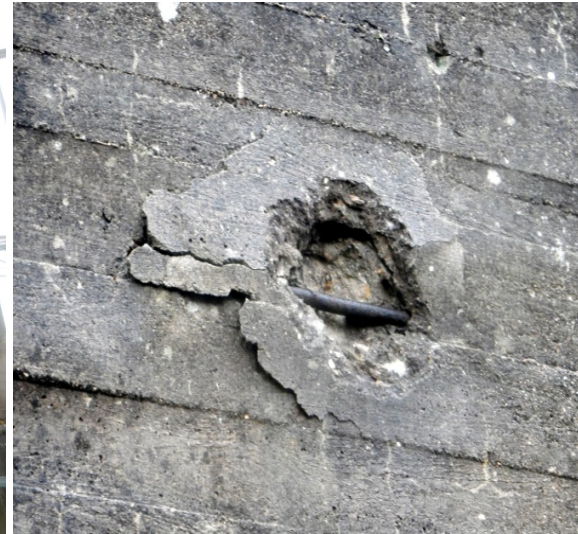

(d)

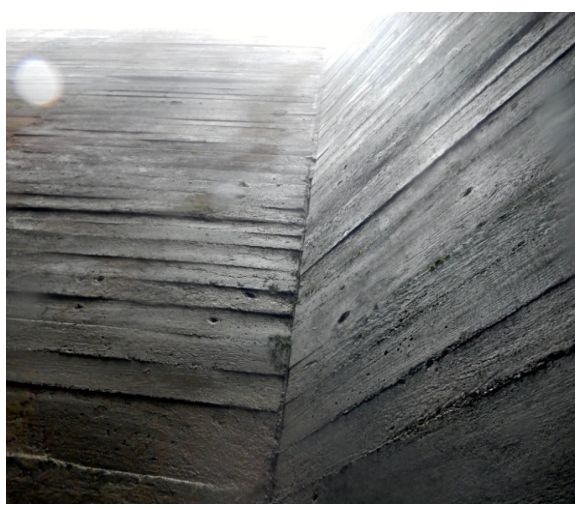

(f)

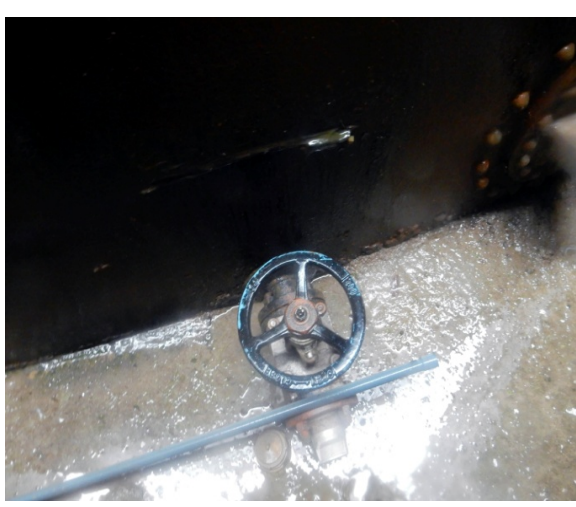

(h) 


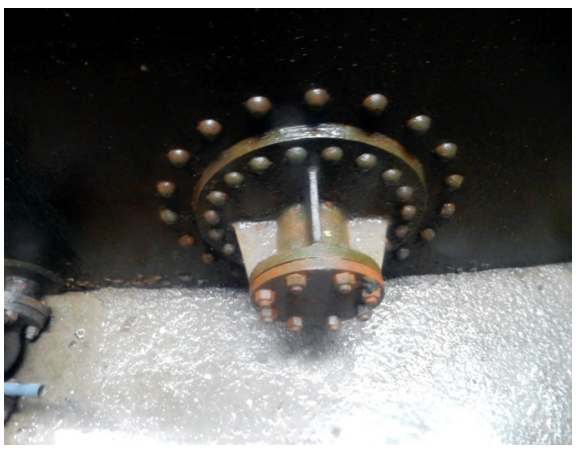

(i)

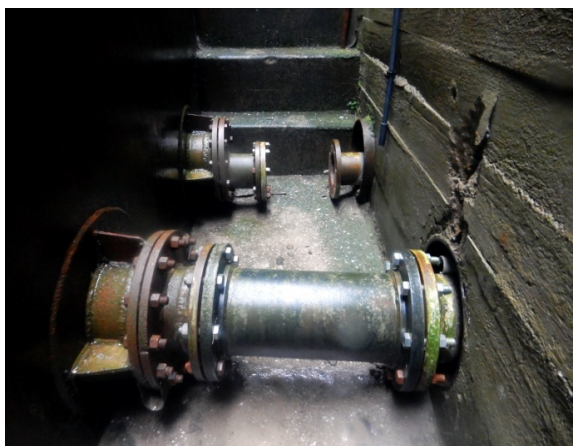

(k)

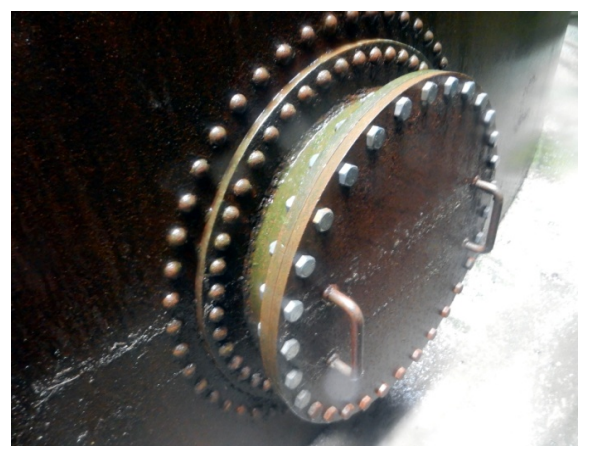

(j)

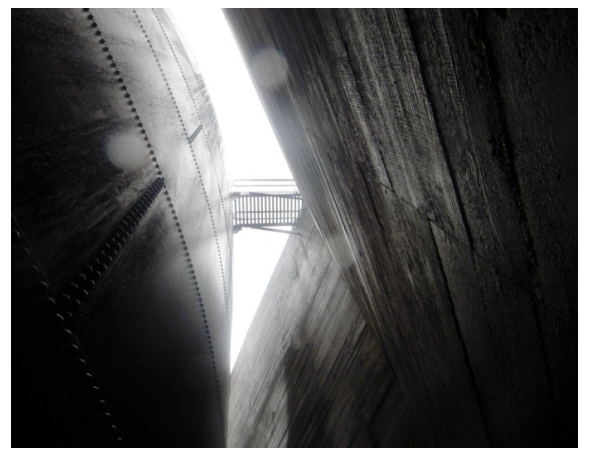

(1)

Figure 15. Octagonal wall E-(a) abraded white board covered by a square blue board; (b) garage leaning against the wall; (c) projectile impact cavities; (d) projectile impact cavity; (e) circular, yellow metallic cover; (f) wall internal structure; (g) metallic pin in the wall; (h) hydraulic valve; (i) riveted tank access; (j) riveted tank access; (k) connection pipes; (l) wall internal structure and tank riveted structure.

the construction formwork elements (Figure 15(f)), typical of the German masonry, confirming its German construction. The tank presented a black, riveted surface with connection pipes crossing the wall.

Six sides wall c $\left(47^{\circ} 25^{\prime} 7.01^{\prime \prime} \mathrm{N}, 0^{\circ} 37^{\prime} 3.79^{\prime \prime} \mathrm{W}\right)$ (Figure $\left.16(\mathrm{a})\right)$ about $17 \times 13 \mathrm{~m}$, which encircled the disappeared tanks 1 to 10 . It presented a well preserved external three step structure without concrete superficial failures and projectile impact cavities.

A manifold $\left(47^{\circ} 25^{\prime} 8.85^{\prime \prime} \mathrm{N}, 0^{\circ} 37^{\prime} 3.25^{\prime \prime \prime} \mathrm{W}\right.$ ) (Figure $16(\mathrm{~b})$ ) about $7 \times 3 \mathrm{~m}$ of polygonal, irregular shape, about two $\mathrm{m}$ deep, near octagonal wall $\mathrm{A}$, containing pipes for the distribution of oil among the tanks. Not present in Figure 10, it was built well after the war. From one of its sides a long pipe gone towards the Bouchemaine freight station.

Bunker i ( $\left.47^{\circ} 25^{\prime} 8.84^{\prime \prime N}, 0^{\circ} 37^{\prime} 6.11^{\prime \prime W}\right)$ (Figure 17(a), Figure 17(b)) about $7 \times$ $3 \mathrm{~m}$, buried in the terrain. The coverage, crossed by pipes and a light bridge, appeared in a good preservation state without damages due to concrete failures or projectile impact cavities. On the coverage were circular holes of about $5 \mathrm{~cm}$ in diameter. The entrance was obstructed by the terrain so that the inspection of the interior was not possible. 


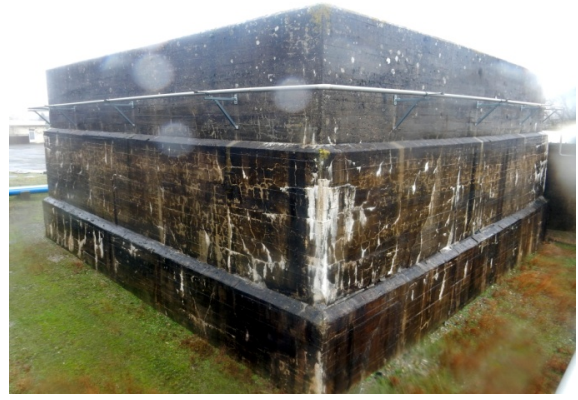

(a)

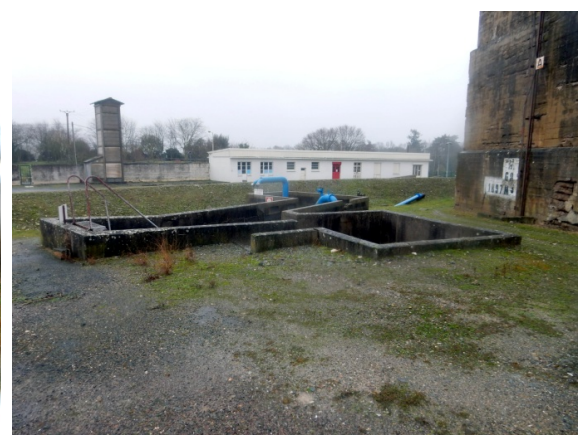

(b)

Figure 16. Bouchemaine oil terminal-(a) six sides wall; (b) after war manifold.

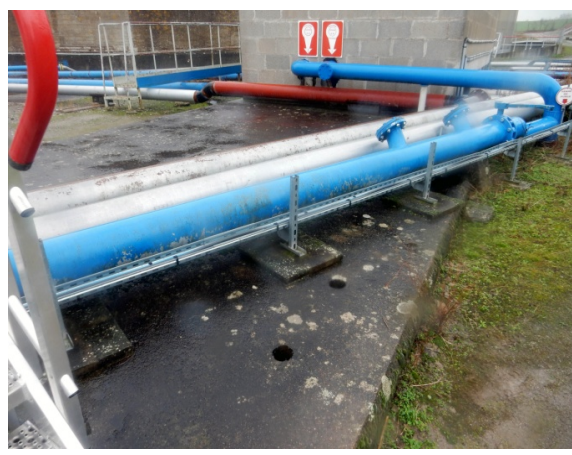

(a)

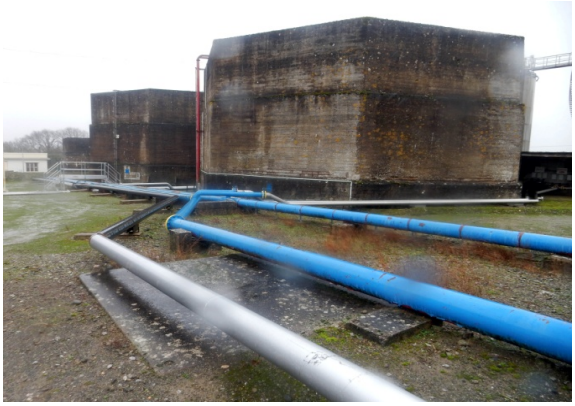

(c)

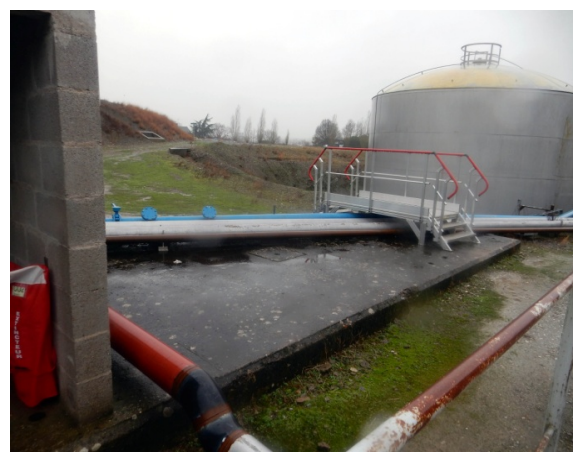

(b)

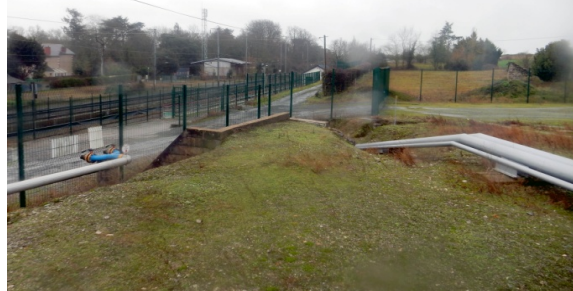

(d)

Figure 17. Bouchemaine oil terminal-(a) bunker i crossed by pipes, west view; (b) bunker i crossed by pipes, east view; (c) possible buried bunker under pipes; (d) pipes exit toward the freight station, in the foreground left the Bouchemaine passenger station.

The entrance/exit o (Figure 18) already presents during the period of the German occupation and now main entrance of the oil terminal. Its concrete structure presented no damages.

No trace on the terrain has been found of the building e, about $60 \times 12 \mathrm{~m}$, the protected passage to the building or anti-tanks trench $\mathrm{f}$ and the excavation $\mathrm{m}$ (Figure 10).

\section{Discussion}

The re-evocations of Rear Admiral Howard-Johnson refers to the days of the operation Aerial in which British and allied forces were evacuated from $15^{\text {th }}$ to 


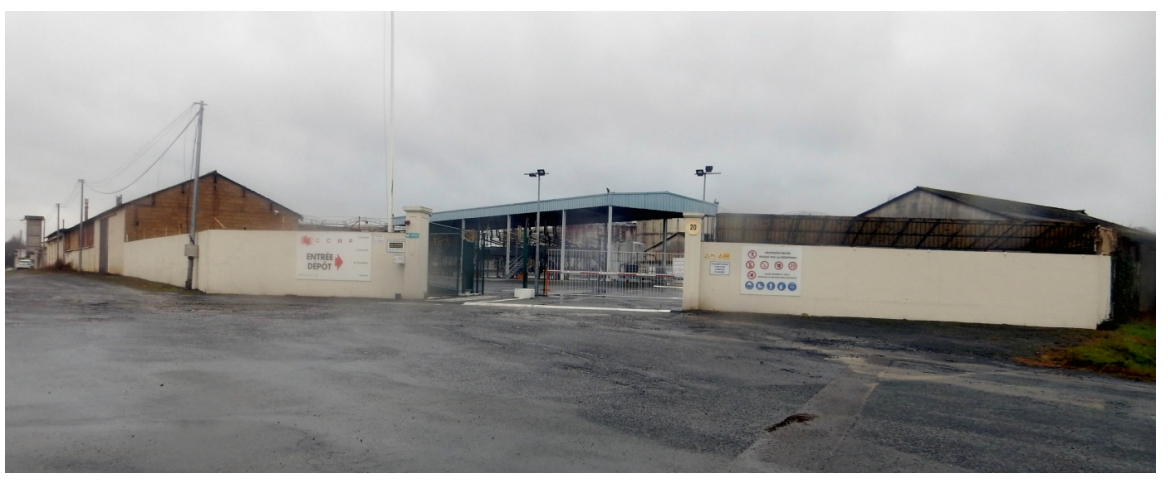

Figure 18. Bouchemaine oil terminal—present main entrance.

$25^{\text {th }}$ June 1940 from west France harbours, after the conclusion of the evacuation operations Dynamo from $26^{\text {th }}$ May to $4^{\text {th }}$ June 1940 from Dunkirk and Cycle from $10^{\text {th }}$ to $13^{\text {th }}$ June 1940 from Le Havre and vividly reflects the chaotic atmosphere of those days.

A French air recognition image of $13^{\text {th }}$ August 1944 (Figure 4), few days after the conclusion of the Saint-Malo battle, reveals many details of the Talards oil terminal. It was composed by a $1^{\text {st }}$ area a comprising a first group of 11 main tanks, a second group of 2 smaller tanks and a third group of 9 still smaller tanks located close one to the other, a $2^{\text {nd }}$ area b comprising 4 tanks, a $3 \mathrm{rd}$ area c comprising 2 tanks and a $4^{\text {th }}$ area $d$ comprising 4 tanks. The tanks of the first group, burned by the Howard-Johnson's group, stored the most required fuel in the region of Saint-Malo, probably gasoline for car and trucks. The fuel supply was ensured by barges and tankers moored to the mooring peer e (Figure 2, Figure 4). After the Battle of Britain no important Luftwaffe unit stationed at the Dinard-Pleurtuit airfield. Therefore, the tanks surviving the burning certainly stored fuels for the Kriegsmarine ships in stop or stationed at the harbour and the Kriegsmarine and Heer vehicles. A pumping station was certainly located on or near the mooring dock e. Because crossing the Channel by oil tankers was dangerous due to the RAF surveillance, it is possible that the fuel came mainly by train, probably from the refinery of Le Havre. A railway contoured the terminal second and third areas b, c; therefore it is possible that the fuel arrived by train was discharged somewhere there, although Figure 4 does not show a railway depot as in the railway station of Bouchemaine (Figure 10). Figure 4 shows that the Germans did not constructed walls for protecting the terminal tanks surviving the burning and that the allied bombardments of Saint-Malo failed to touch the terminal.

The questions about: the possible German oil terminal requisition, the volumes and oil kinds actually dealt with at the terminal during the war, the reason for which the oil terminal was not dynamited by the Germans during the battle of Saint-Malo, and many other possible questions concerning the Talards oil terminal remain to be answered.

A French air recognition image of $17^{\text {th }}$ September 1944 (Figure 10), exactly 
one month after the conclusion of the Saint-Malo battle, reveals many details of the Bouchemaine oil terminal. As the Talards oil terminal, it was composed by a 1st area a comprising, in this case, a first group of 4 main tanks each protected by an octagonal wall and a second group of 10 smaller tanks located close one to the other and all protected by a six sides wall. The fuel supply was ensured by trains, which parked in the railway depot $\mathrm{s}$ and by barges and tankers coming from the refinery of Donge, which moored at the oil dock $\mathrm{d}$. The main columnar bollards were so big and high for a sure mooring of barges and tankers in the Maine stream also during the Maine floodings, in which the dock platform was covered by water. The pumping station on the top of columnar bollard c permitted oil pumping also during the floodings. Because no sign of German masonry was remarked, the dock platform and its bollards were of French construction. The small bunker $h$ at the terminal entrance was probably a guardhouse and the bunker i a refuge for the personnel lodged in the building e or an ammunition and material depot bunker. The excavation $m$ inclined with respect to the $S N C F$ railway (Figure 10) reveals the German intention to expand the railway depot $s$ by constructing a second, protected railway depot opposed with respect to the $S N C F$ railway to the depot s. The adaptation of the oil terminal to the Kriegsmarine needs and the excavation m were probably directed by the Organization Todt supervising the work of French requisitioned firms, workers and vehicles. The oil terminal $t$ and the tank wagons parked in the depot $s$ have not been object of attacks by the French resistance. The nearby suspended bridge on the Maine (Figure 7(a)), considered of strategical importance, was dynamited by the Germans in retreat with the loss of one of its two ways (Figure 5).

The questions about: why the oil terminal was requisitioned by the Kriegsmarine and not by the Heer or the Luftwaffe, why the requisition was made in June 1941 and not before, which were the volumes and the oils actually dealt with at the terminal during the war, if the oil terminal supplied in kerosene the Luftwaffe fighters and bombers Stuka and Dornier of the $10 \mathrm{~km}$ far away, today disappeared, airfield of Avrillé (Angers), the reasons for which the oil terminal and the oil dock were not dynamited by the Germans in retreat, and many other possible questions concerning the Bouchemaine oil terminal remain to be answered.

\section{Conclusion}

In previous articles, fundamental emerged the role of witnesses and experts for identifying and explaining surviving or disappeared structures of the Atlantic Wall. In this article, further emerged fundamental the roles of original air recognition images for identifying surviving and disappeared oil terminal components, of visits on the sites for ascertaining their morphology and preservation states, of archive researches for reconstructing the oil terminal histories and of discussions with experts for understanding aspects of the involved technologies. All this shows that the study of the Atlantic Wall should be conducted in an interdisciplinary way with the support of experts in different technical fields. 


\section{Acknowledgements}

I express my gratitude to Mr. L. Pottier for sharing the results of his researches about the Talards oil terminal in the Archives Municipales de la Ville de Saint-Malo, to Mr. F. Guillaume for sharing his technical knowledge and information about the Bouchemaine oil terminal and for having guided me during the visit on the oil terminal site and to $\mathrm{Mr} \mathrm{A}$. Benoit for sharing digitalised original WWII documentation concerning the Bouchemaine terminal.

\section{References}

Archives Municipales de la Ville de Saint-Malo (1940). Registre du Cadasdre $N^{\circ} 2256$ et 2257.

Brichet, O., \& Peyle, E. (2005). La Marine Allemande à Saint-Malo, 1940-1944 (pp. 71, 115). Cancale: Editions du Phare.

Dahiot, D., Dupont, P., Pottier, L., \& Tomezzoli, G. (2009). Die Infrastruktur des Fliegerhorstes Dinard-Pleurtuit im II. Weltkrieg. DAWA Nachrichten. Ausgabe, 53, 42-61.

Lippmann, H. (2012). Die Flugabwehrsicherung des Fliegerhorstes Dinard-Pleurtuit. DAWA Nachrichten. Ausgabe, 60, 4-13.

Oil Terminal Archive Bouchemaine (2018). Digitaliseddocumentation.

Pottier, L. (2013). Personal Archive.

Tomezzoli, G. (2014). Der Gefechtsstand der Flak Abteilung 912 auf dem Gelände des Fliegerhorstes Dinard-Pleurtuit. DAWA Nachrichten. Ausgabe, 63, 20-27.

Tomezzoli, G. (2015). The Kieswerk of Pointe Saint-Mathieu and the Atlantic Wall. $A d-$ vances inAnthropology, 5, 177-182. https://doi.org/10.4236/aa.2015.54017

Tomezzoli, G. T. (2016). The German Base "the Bank" at Mûrs-Érigné (Anjou-FR). Archaeological Discovery, 4, 37-47.

Tomezzoli, G. T., \& Pottier, L. L. (2016). Journey through the Defences of the Festung Saint-Malo (FR)-2. Archaeological Discovery, 4, 143-169.

https://doi.org/10.4236/ad.2016.44011

Tomezzoli, G., \& Marzin, Y. (2015). The EroVili and the Atlantic Wall. Advances in Anthropology, 5, 183-204.

Tomezzoli, G., Pottier, L., \& Dahiot, D. (2013). La logistique et les défenses de l'aérodrome dePleurtuit (Bretagne-FR) pendant la guerre. L'écho de la Cohue No. 14, Patrimoine du Pays dePleurtuit en Poudouvre. 